\title{
Green without envy: how social capital alleviates tensions from a Payments for Ecosystem Services (PES) program in Indonesia
}

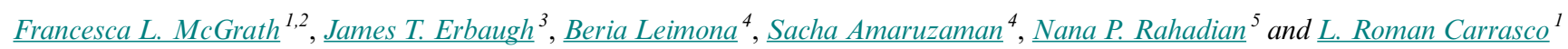

\begin{abstract}
Social capital increases participation and the success of conservation projects. However, research often overlooks social capital between program participants and nonparticipants. We examine social capital between participants and nonparticipants in villages across the Cidanau Watershed in West Java, Indonesia. Villages in this region have longstanding participation in a Payments for Ecosystem Services (PES) scheme, and previous studies note they contain high levels of social capital. We find that working together, helping each other when someone is in need, and trusting your neighbors are part of the tradition and the history of these communities. Furthermore, we find that high levels of social capital persist between village members who do and do not participate in the PES scheme, despite perceived tensions and jealousy and elite capture in the PES scheme. The high levels of social capital mitigate the social impacts of the PES program. Specifically, participants report giving cash to jealous neighbors and/or providing nonparticipants with information about the PES scheme and encouraging their involvement. The informal actions that participants take to alleviate tension and jealousy mitigate the negative social impacts and perceptions of the PES. Thus, this research extends the literature on PES programs to consider participants and nonparticipants and it demonstrates how high levels of social capital can contribute to project stability by alleviating negative consequences and perceptions through informal mechanisms.
\end{abstract}

Key Words: incentive-based conservation; Indonesia; payments for ecosystem services; social capital; social impacts

\section{INTRODUCTION}

Payments for ecosystem services (PES) are becoming increasingly common in natural resource governance (Barnaud et al. 2018). Support for PES programs stems from their ability to promote the conservation of nature and the supply of ecosystem services through the use of incentives, and thus provide social and ecological benefits (Gómez-Baggethun et al. 2010). However, as with any policy implementation, it is important to understand the preconditions that enable success of PES schemes, as well as the way in which these schemes affect communities that participate in them. Identifying beneficial preconditions supports practitioners in targeting sites and communities best positioned to benefit from and engage with PES programs; understanding the role PES schemes play in altering community relationships ensures the ethical implementation of policy interventions. Payments for ecosystem services programs often occur within local social-ecological systems (SES), and social capital can directly influence the success of institutions within these existing systems (Koontz et al. 2015). Building on existing institutions within communities can help aid in the implementation and facilitation of PES schemes. Thus, this research seeks to understand the social preconditions that best anticipate PES program success, and how PES can influence social capital.

Building social capital has become a common component when implementing projects for environmental management and conservation. As people work together to build new relationships, institutions, rules, and social norms, they demonstrate a deeper understanding and commitment to project goals and objectives (Pretty and Smith 2004). For example, Bouma et al. (2008) find that social capital positively influences households' participation in social and water conservation maintenance and infrastructure. Krishna and Uphoff (1999) also find that social capital is positively correlated with improvement in development outcomes in a watershed development project in India. Similarly, social capital has been found to have an important influence on positive biodiversity conservation outcomes (Thuy et al. 2011). Community-based conservation in communities with strong social links and networks that are well organized can also be more conducive to incentive-based schemes, such as PES (Cranford and Mourato 2011).

\section{Box 1: What is social capital?}

Social capital refers to the processes and networks within a society helping work toward the common good based on trust, reciprocity, and solidarity (Campos et al. 2015). It comprises five components: 1 . groups and networks, 2. trust and solidarity, 3 . collective action and cooperation, 4. information and cooperation, and 5. empowerment and political action. In addition, social capital occurs in three different forms: bonding, bridging, and linking (Woolcock and Narayan 2000, Pretty and Smith 2004). Bonding is social capital that exists between those in similar circumstances, for example, family and close friends. Bridging refers to the capital between more distant individuals, such as work colleagues. The final form, linking, is a more vertical relationship between those within and outside of a community, such as between community members and external government workers.

\footnotetext{
${ }^{1}$ Department of Biological Sciences, National University of Singapore, 14 Science Drive 4, Singapore 117543, Republic of Singapore, ${ }^{2}$ School for Environment and Sustainability, University of Michigan, 440 Church Street, Ann Arbor, Michigan, 48109, USA, ${ }^{3}$ Environmental Studies Program, Dartmouth College, Hanover, New Hampshire 03755, USA, ${ }^{4}$ World Agroforestry Centre (ICRAF), JL, CIFOR, Situ Gede Sindang Barang, Bogor 16115 PO Box 161, Bogor 16001, Indonesia, ${ }^{5}$ Rekonvasi Bhumi, Jalan R.H. Joenus Soemantri, No 4/20, RT 1, RW 1, Kelurahan Tembong, Kecamatan Cipocok Jaya, Kota Serang, Provinsi Banten, Indonesia
} 
Fig. 1. Map of the Cidanau watershed; data source: World Agroforestry Centre (ICRAF).

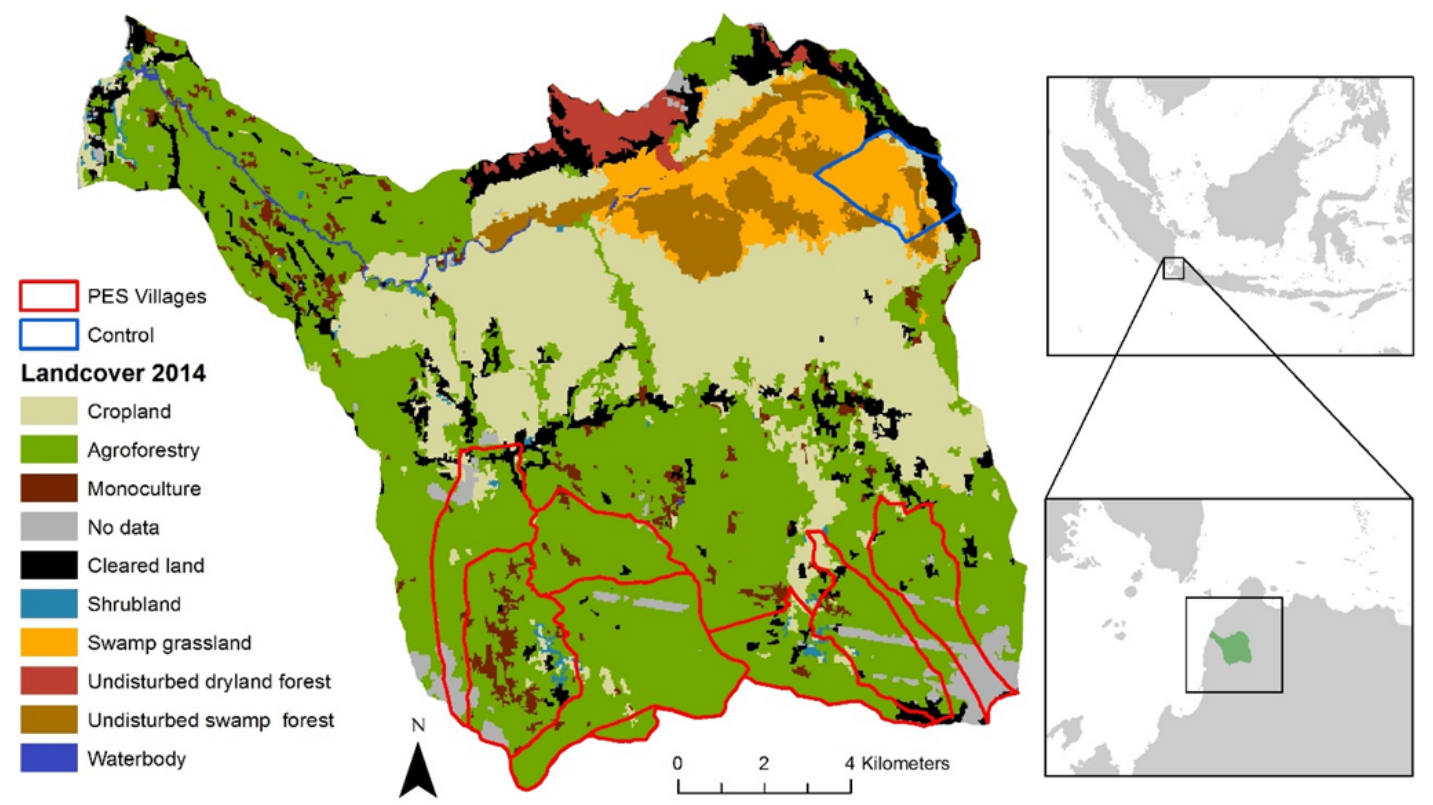

Within current research, there has been a limited focus on how PES affects social capital when contracting at the group level, and even less focus on how these schemes alter the social capital of participants and nonparticipants (Huang et al. 2009, Tacconi et al. 2009). Although providing PES in communities with strong social capital may facilitate conservation outcomes (Cranford and Mourato 2011, Nieratkaa et al. 2015), this approach fails to acknowledge the potential negative impacts on social capital for nonparticipants in the PES scheme. Given time and budgetary limitations, most PES schemes are unable to provide unlimited payments to all individuals within a community. Unequal power balances (Baker and Chapin 2018) and an exacerbation of existing inequalities can occur when some individuals within a village can access a program, whilst others cnnnot. This is particularly important in communities that are dominated by one occupation (e.g., farming), and the PES scheme only engages a select proportion of the population. This could then lead to an increase of social capital between the smaller contracted group negatively impacting those not contracted (Ostrom and Ahn 2003).

The potential for selective participation to impact social dynamics has been found in other systems. For instance, in rural country towns with a keen interest in sport, failing to participate in sporting activities can lead to social exclusion (Greble 1979). Furthermore, even in voluntary associations for politics, social capital has been known to differ between participating and nonparticipating groups (Wollebaek and Selle 2002). If individuals within a larger community already have strong social capital, a PES scheme that only contracts a set of few individuals may risk eroding these previously strong social links. Furthermore, social capital is not only created but can be transformed, weakened or in some cases destroyed (Ostrom and Ahn 2007). Thus, the negative consequences of social capital can reinforce inequality, relating to power asymmetries, and may reinforce antisocial behavior (Field 2008, Adhikari and Goldey 2010).
Participants' and nonparticipants' perception of the PES scheme is a key determinant if the scheme is to be judged as socially legitimate (Narloch et al. 2013). Furthermore, the positive perception of conservation interventions can improve the implementation, monitoring, and evaluation of the actions at hand (Bennett 2016). Infield and Namara (2001) find that communities that were participating in a conservation program had positive attitudes toward wildlife and the park in contrast to the other communities that did not benefit. Monitoring these social impacts and indicators are thus crucial in conservation projects (Sommerville et al. 2010). In this study, we first assess whether there are differences in social capital between participating and nonparticipating farmers in a longstanding PES scheme in Cidanau, Indonesia. Second, we investigate whether there is perceived tension and jealousy caused by the PES scheme and if there are mechanisms used in the community to alleviate the tension. Finally, we identify characteristics that make certain individuals more likely to participate in the PES to assess whether the scheme led to elite capture.

\section{Study site}

The Cidanau watershed (Fig. 1) is located on the island of Java in Indonesia. The 22,036-ha large watershed is one of the most important hydrological systems in western Java, supplying water for domestic and industrial consumption across Banten Province. Due to decreasing forest cover, land erosion, and siltation, the downstream water quality from Cidanau has decreased substantially over the past few decades (Lapeyre et al. 2015). Remote sensing has found that around $71 \%$ of the watershed is prone to degradation (Leimona et al. 2010).

Due to concerns about watershed quality, a combination of government, nongovernmental organizations (NGOs), and corporate actors created a multistakeholder communication forum (Forum komunikasi das Cidanau (FKDC)). This forum 
assists with planning and conserving land within the Cidanau watershed, with a focus on reducing soil erosion by conserving forest area and rehabilitating land with steep inclines. Within this forum, a local NGO, Rekonvasi Bhumi, was tasked with implementing a PES scheme that incentivizes local farmers to plant/maintain tree cover and increase water filtration. Members of the FKDC acted as intermediaries between PES participants and PT Krakatau Tirta Industry (KTI), a private company that collects the water from Cidanau where it is processed and distributed for domestic and industrial consumption. Krakatau Tirta Industry funds the PES program, which treats each of the 11 farmer groups as one homogenous unit. All groups have approximately 25 ha of land in total, with group size ranging from 25-77 individual members. Contracted farmers were paid approximately \$135 USD per ha per year.

\section{METHODS}

\section{Identifying survey respondents}

The primary form of data collection in this research was a survey disseminated to farmers who participated in the PES scheme. Within the survey, we identified two respondent groups: farmers participating in the PES program (herein referred to as "PES farmers") and farmers not participating within the PES program (herein referred to as "nonPES farmers") but located in the same village as PES farmers. All farmers within our study were members of an associated farmer group. Rekonovasi Bhumi (the local NGO) provided a list of PES farmers, which served as our sample frame. From this sample frame, we randomly selected PES farmers to participate in our survey. NonPES farmers were identified using a snowball sampling approach. In total, we surveyed 255 respondents (187 PES and 68 nonPES farmers).

\section{Survey content and variables collected}

We use the World Bank core social capital integrated questionnaire (IQ-SC) to measure respondents' social capital (Grootaert et al. 2004). Specifically, we focused on the aspects of cognitive social capital. The survey also contained questions about socioeconomic characteristics, including farmer demographics and agricultural plot information (Append. 1). We collected information on whether the farmer was the family head, whether they were a farmer group leader, farmer's age, years of education, if the family helps with the plot, number of family members, if they have a second job, if they come from the area, if they have a loan, and their asset category. Further data were collected on the farmer's plot characteristics, including the average plot size, plot distance to their house, plot distance to village, what they grow, and whether they have multiple farming plots.

A native speaker familiar with PES translated the survey instrument, and two specialists validated it. The survey instrument was disseminated by four enumerators who received training in interview and survey completion technique, including multiple pilot (i.e., practice) interviews. All surveys were completed in November 2016.

\section{Analyses}

We used a mixed methods approach to understand how the PES scheme has influenced social capital between participants and nonparticipants. First, we analyzed the demographic and social capital data using descriptive statistics for each of the social capital components as listed below. These are: 1. groups and networks, 2. trust and solidarity, 3. collective action and cooperation, 4. information and communication, and 5. empowerment and political action.

We matched our data set to increase the overlap and balance between the treatment groups. Statistical matching is a nonparametric method to control for selection bias. Using an algorithmic method, pairs of "treatment" and "control" observations are matched based on a set of covariates theorized to influence both selection (in this case, selection to become a PES farmer) and the outcome of interest. We matched our data set using the "MatchIt" package in R (Ho et al. 2017). Our treatment variable was individuals contracted into the PES (1), or not contracted (0). The covariates on which we matched PES and nonPES farmers include the demographics and plot details. We examined eight different matching methods (optimal, full, genetic, nearest neighbor, exact, subclass, coarsened exact, and Mahalanobis) to identify the best fit for the data using mean differences. In our case, the nearest neighbor approach had the best matching fit. This matched data set was then used for the rest of the analyses. The matched data set included 68 PES and 68 nonPES for a final sample size of $n=136$. The rest of the observations were excluded from the analyses.

Second, to understand the differences between the characteristics of those contracted or not, we ran a generalized linear model (GLM) with a binomial distribution. We used an information theoretic approach to determine which models were best supported by the data (Burnham and Anderson 2002). We proposed three candidate models with increasing complexity: model formula 1 included demographic variables, model formula 2 included demographic and asset variables, and model formula 3 included demographic, asset, and plot variables. We assessed models for multicollinearity and evaluated model fit using the lowest Akaike information criterion (AIC). The final models represented the lowest AIC value.

\section{Follow-up focus group discussions}

After the data set was analyzed, we completed six follow-up focus group discussions (FGD) to verify and interpret the findings of the data analysis in June 2017. We conducted four focus groups (two with leaders, two with members) with PES members and two focus groups (one with leaders, one with members) with nonPES members. Leaders were separated from active group members to control for potential response bias. Each FGD had between 5-9 participants.

\section{RESULTS}

We find that PES and nonPES households do not significantly differ in terms of social capital. The FGDs reveal the mechanisms behind this nonsignificant finding: specific intervillage practices reduce tensions and jealousy between participating and nonparticipating households. However, the PES participating households appear to have more assets and multiple plots.

\section{Household demographics}

From the descriptive statistics, it appears that the PES farmers have more varied asset ranking levels, whereas the nonPES group cluster around a medium asset level (Table 1). The majority of land tenure is "milik," meaning the farmers have land ownership rights (de jure). A small percentage of PES farmland are "garap" tenure, which is more nuanced, but ultimately means the farmer 
has been acknowledged by a local official to "occupy the land," squatting form of de facto property ownership (Global Land Tool Network (GLTN) 2015). The two groups produce a similar set of crops, the most common being melinjo (Gnetum gnemon), clove (Syzygium aromaticum), durian (Durio sp.), and jengkol (Archidendron pauciflorum).

Table 1. Characteristics of the farmers (PES and nonPES)

\begin{tabular}{|c|c|c|}
\hline & $\operatorname{PES}(n=68)$ & nonPES $(n=68)$ \\
\hline \multirow[t]{3}{*}{ Age } & Minimum - 25 & Minimum - 25 \\
\hline & High - 80 & Maximum - 73 \\
\hline & Mean - 49 & Mean - 46.94 \\
\hline \multirow[t]{3}{*}{ Education } & Minimum - 1 & Minimum - 2 \\
\hline & Maximum - 14 & Maximum - 17 \\
\hline & Mean - 6.63 & Mean - 6.22 \\
\hline Ethnicity & Sundanese - $100 \%$ & Sundanese - $100 \%$ \\
\hline \multirow{2}{*}{ Are they a migrant? } & Yes - $94 \%$ & Yes - $97 \%$ \\
\hline & No $-6 \%$ & No $-3 \%$ \\
\hline \multirow{3}{*}{$\begin{array}{l}\text { Number of family } \\
\text { members }\end{array}$} & Minimum - 0 & Minimum - 0 \\
\hline & Maximum - 9 & Maximum - 10 \\
\hline & Mean - 4.4 & Mean - 4.28 \\
\hline \multirow[t]{2}{*}{ Second job } & Yes - 37\% & Yes $-35.2 \%$ \\
\hline & No $-63 \%$ & No $-64.8 \%$ \\
\hline \multirow[t]{2}{*}{ Loan } & Yes $-6 \%$ & Yes $-9 \%$ \\
\hline & No $-94 \%$ & No $-91 \%$ \\
\hline \multirow[t]{3}{*}{ Asset } & Low - $38 \%$ & Low $-8.8 \%$ \\
\hline & Medium - 37\% & Medium - 82.4\% \\
\hline & High - $25 \%$ & High - $8.8 \%$ \\
\hline \multirow[t]{3}{*}{ Average plot size } & Minimum - 0.06 & Minimum - 0.01 \\
\hline & Maximum - 1.5 & Maximum - 2 \\
\hline & Mean - .5348 & Mean - .6316 \\
\hline \multirow[t]{2}{*}{ Plot tenure } & Milik - 98\% & Milik - 100\% \\
\hline & Garap - 2\% & \\
\hline \multirow[t]{4}{*}{ Top four crops } & Melinjo -39.1\%; & Melinjo - 36.5\%; \\
\hline & Cengkeh - $20.7 \%$ & Cengkeh - $26.9 \%$; \\
\hline & Durian - $14.8 \%$ & Durian - 11.9\%; \\
\hline & Jengkol - 8\%; & Jengkol - $6 \%$; \\
\hline
\end{tabular}

\section{Social capital 1: groups and networks}

Results from the social capital survey (Append. 1) on groups and networks demonstrate similar trends between PES and nonPES households. We find that PES participants are marginally more likely to be able to borrow money to cover one week's household expenses (Table 1 in Append. 1). In FGDs, PES farmers said after joining the scheme they were better able to borrow money from within their contracted group or from group leaders who allocated the PES. They stated that before the PES scheme it was more difficult to borrow money, as you would need collateral (i.e., trees or fruit). NonPES respondents indicated they were only able to borrow money with collateral, and not from any existing money pot. A series of slight group differences also differentiate PES and nonPES households. NonPES farmers were more likely to be in contact with outsiders (48\%) compared with the PES farmers $(32 \%)$. Additionally, PES farmers are more likely to have different occupations within their group (40\% listed the same occupation) compared with nonPES farmers $(65 \%$ listed the same occupation).

\section{Social capital 2: trust and solidarity}

The PES households are less trusting of the village officials compared with the nonPES. The PES group are also more likely to respond that they need to be alert so that someone does not take advantage of them. However, when asked how much they trusted members within the FGs, PES farmers reported slightly higher levels of trust than nonPES farmers did. Within the FGDs, many farmers from the PES group stated that they trust the people involved with the PES scheme (e.g., local NGO, those who do the monitoring and verification). They were also keen to discuss how they do not trust village outsiders. One discussion point common to both PES and nonPES FGDs regarding trust is the importance of demonstrated evidence of word-turned-deed, phrased as the need to "see it with their own eyes." Focus group discussion participants from both PES and nonPES groups said that many people "talk without action."

\section{Social capital 3: collective action and cooperation}

NonPES farmers are more likely to believe that people will come together and cooperate to solve a problem faced within the village. Furthermore, the nonPES group are less likely to give money to a village cause (84\%) compared with the PES group $(94 \%)$. Throughout all of the FGDs, both PES and nonPES individuals agreed that collective action and cooperation occurred frequently within their villages. All participants emphasized that working together within these villages is part of the tradition, and that if anyone needs help, the village community will come together to solve the problem. Participants from both PES and nonPES groups indicated that, when the government has asked for help, community members would seek reimbursement of their time, rather than helping with no strings attached.

\section{Social capital 4: information and cooperation}

Responses concerning information and cooperation demonstrate no major differences between both the PES and nonPES groups. Both groups feel safe at home and frequently socialize with others. The ethnicity, economic status, social status, and religion of those that they socialize with was the same for both groups (Table 1 in Append. 1).

\section{Social capital 5: empowerment and political action}

Similar to "Information and cooperation," we found similarities between the PES and nonPES responses on general happiness, and whether respondents feel they are able to make important life decisions to change their lives, all being positive.

\section{Tensions and jealousy results}

The FGDs reaffirm findings from the social capital questionnaire. The questionnaire indicated that all farmers responded as having strong groups and networks, high levels of trust with one another, high amounts of information and communication, and intervillage cooperation. However, FGDs indicate that jealousy and tensions exist between PES and nonPES groups. NonPES farmers stated that they do not understand why they are not contracted into the PES, as their plots are in the same locations, they grow the same fruits and vegetables, and they have the same income as the PES farmers. Furthermore, some nonPES farmers originally declined to participate in the PES scheme, in order to continue using their trees as collateral for loans. The FGDs revealed differences between PES and nonPES farmers' perceptions of dissatisfaction. All PES and nonPES farmers 
agreed that the tensions and jealousy started when the farmers initially received their PES contract payment. In some cases, the tensions and jealousy decreased after this initial payment, whereas some groups reported that they have remained at the same level.

Given that high levels of social capital were present, but tensions and jealousies were reported, farmers were asked to explain the mechanisms behind this. Both groups stated that communities alleviated jealousy and tensions in one of two ways: PES farmers gave money or shared information about joining the PES scheme information to their jealous neighbors. During the FGDs, PES farmers who gave money described how they would only give money to jealous neighbors and not to all of their neighbors after each PES payment date. Furthermore, the nonPES farmers were all keen to join the PES scheme if it were to expand. Previously it has been argued that nonparticipants may change their behavior in a bid to be accepted onto the scheme in the future. When asked this, we found that the nonPES farmers were currently not doing any required $\mathrm{PES}$ scheme action (e.g., they were cutting their trees whenever they wanted). However, we did find that some of the nonPES groups have started trying to fulfill some of the PES group requirements (e.g., having all land in one area).

\section{Probability of being contracted in the PES scheme}

Farmers with multiple plots were more likely to participate into the PES scheme, showing evidence of elite capture ((Estimate \pm Standard Error) $5.28 \pm 1.08$ ) (Fig. 2). We also find that if the farmers did not have family help on their plot $(-3.75 \pm 1.01)$, have a medium asset level $(-2.91 \pm 1.16)$, and have a loan (-1.35 \pm 1.63$)$, they were less likely to participate in the PES.

Fig. 2. Parameter estimates with confidence intervals for GLM model on characteristics of PES and nonPES farmers, identifying elite capture.

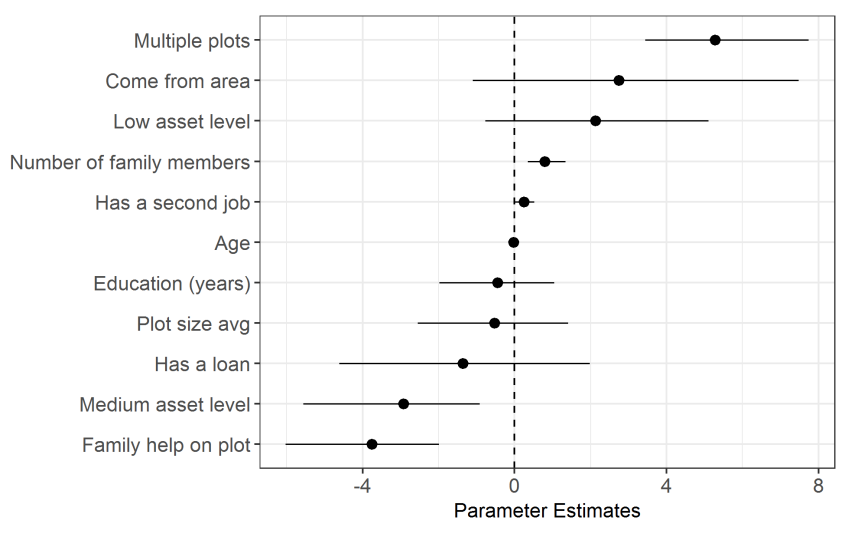

\section{DISCUSSION}

\section{PES and nonPES participant social capital}

Across the households of both PES and nonPES farmers that were surveyed, we found high levels of social capital. Interestingly these high levels of social capital appear to be not affected by the PES scheme and their associated shocks/impacts. This resilience of the social capital is occurring through informal transfers of money and information within the communities. Our results provide empirical evidence of nonsignificant differences between the social capital of the PES and nonPES groups. Instead, we found that these villages have very high levels of social capital, which enabled them to reduce jealousy and tension between PES participants and nonparticipants.

Overall, we found a consistently high level of social capital from the surveys and FGDs. These results are similar to the findings of Leimona et al. (2010), which suggest some tensions are present but overall social capital is high. When asked about trust, most PES and nonPES farmers stated that their trust had remained constant over time, all emphasizing their lack of trust of outsiders. Trust is an important part of social capital, lowering transaction costs by reducing opportunistic behavior of individuals (Becchetti et al. 2013). Building on this, trust and performance can mutually affect each other in collective action organizations (Ostrom 1990, Adger 2003, Becchetti et al. 2013). Results regarding collective action were consistent across both groups of PES and nonPES. Collective action is well established within rural communities in Java (Djamhuri 2008). For example, "gotong royong" is a unique Javanese concept that is often defined as the cooperation within and between social networks (Kusumasari and Alam 2012). The spirit of gotong royong puts an emphasis on communal activities and helping one's neighbor (Bowen 1986). The FGDs show that PES farmers alleviate negative social consequences by giving money and information to nonPES farmers, a phenomenon reported to have occurred in other cases of natural resource management in Java (Djamhuri 2008). All participants in the FGDs expressed how working together is a tradition within their communities. Other studies support our findings, demonstrating that rural Javanese communities participating in natural resource management have high levels of social capital (Lee et al. 2017).

Importantly, social capital and resilience are related in two distinct ways. First, the resilience of social capital and second, how social capital promotes community resilience. Community resilience is theorized to reside in the strength of social networks (Rockenbauch and Sakdapolrak 2017). Within the research on social capital, more emphasis has been placed on how social capital can promote community resilience. Our research focuses on the former and indicates that when there are high levels of social capital, this social capital is resilient to changes caused by economic incentive programs (e.g., PES scheme). A feeling of community with connection, support, and collective problem solving can play a pivotal role in a group's ability to engage with natural resource management (Baker and Chapin 2018). Social capital within Javanese rural communities facilitates benefit sharing between participants and nonparticipants and also facilitates the existence and effectiveness of collective action for forest initiatives (Djamhuri 2008). Building on this leadership is a crucial aspect of social capital, facilitating in information dissemination, collective action, and conflict resolution. Leadership often involves someone with power, and it has been previously found that transfers (e.g., knowledge, communication) within a resource management scheme rely on these power relationships (Lauber et al. 2008).

This study illustrates how informal methods of benefit sharing (money and/or information) can mediate jealousy and tension between participants and nonparticipants, maintaining high levels of social capital. This informal information dissemination could help the scheme if it were to expand in these villages. Using 
the high social capital in a community to facilitate future PES scheme expansion is currently an understudied area. These social networks can be vital for communication and sharing knowledge (Lauber et al. 2008, Ramirez-Sanchez and Pinkerton 2009). Social learning and information sharing can increase the adoption of conservation measures (Dessie et al. 2012). In the FGDs, we find that the nonPES farmers are all keen to join the scheme based on the information they have been given from the PES farmers. It has also been hypothesized that groups with greater communication with outsiders are more likely to have easier access to resources, which they can use to benefit the group (Oh et al. 2004). In the case of Cidanau, it could be that the PES farmers are disseminating these resources beyond their immediate farming PES group (e.g., giving information) and thus the nonPES farmers are not experiencing any decrease in their own groups and networks.

Increasing and utilizing social capital can reduce implementation costs of community-based conservation (Farley and Costanza 2002). Further to this, high social capital in rural communities can increase technology diffusion and environmental management (García-Amado et al. 2012, Teshome et al. 2016), and encouraging this multiactor collaboration is necessary to improve governance arrangements (Bodin et al. 2016). However, a collaborative approach and changes in social capital can lead to more conflict as tensions and power relations are brought to the forefront (McDougall and Banjade 2015). Building on this, although high levels of social capital are largely beneficial, they include some potential negative consequences (Ostrom 1999, Ballet et al. 2007). One consequence of high social capital may have been that the PES farmers may have felt social pressure to join the scheme and maintain a good reputation (Lapeyre et al. 2015). Another consequence could be with the PES scheme monitoring and the PES farmers' reluctance to report rulebreaking (Bodin and Crona 2008). Furthermore, it has been argued that social capital fails to acknowledge how potential power asymmetries influence social networks and the subsequent access to resources (Wall et al. 1998). Despite these negative consequences, the benefits of high levels of social capital have been well explored in community-based conservation (Plummer and FitzGibbon 2006), but have not yet become a resource for PES schemes and other incentive-based conservation programs (Guerrero and Wilson 2017).

\section{Who is contracted into the PES scheme?}

Those with greater wealth were more likely to participate in the Cidanau PES scheme. This reaffirms previous studies that find households with greater wealth are better equipped to participate within natural resource management due to their availability of resources (Dasgupta and Beard 2007, Baker and Chapin 2018). Within the FGDs, we asked whether PES scheme payments caused this greater wealth, or whether participant wealth was exogenous to participation. All farmers (PES and nonPES) agreed that the payment amount from the PES is not enough to significantly increase the farmers' income (i.e., making them "rich"). This indicates that the farmers participating in the scheme were wealthier before it began, potentially suggesting that there is some elite capture within the schemes implementation. Many other studies provide examples of when PES schemes favor participation from wealthier community members. In Bolivia, for example, tensions increased when nonparticipants believed that a PES program only included the richest community members, increasing economic inequalities (Turiansky 2010). However, in the Cidanau PES scheme, nonPES farmers reported that elite capture was not an issue. Some agreed that the wealthier farmers were participating, whereas others stated that they thought this was not the case. In both situations, no farmers believed that this was causing any social tension or jealousy.

There are important implications from the finding that the Cidanau PES scheme favors participation from wealthier farmers, but that this does not generate intervillage tensions. Elite capture is considered a risk for PES schemes (Pascual et al. 2014) and can yield negative consequences in certain scenarios. In the Scolel Té carbon forestry project, elites captured the PES benefits due to their political affiliations and larger landholdings, which led to conflicts between participants and nonparticipants (Corbera et al. 2007). In a further example, elite capture in Vietnam is said to be one of the key challenges in PES scheme implementation due to the monopolization of access to forest land (To et al. 2012). Elite capture can potentially widen the wealth gap between the poorest and richest members in a community, and high transaction costs can be a significant barrier (Caro-Borrero et al. 2015). In the Cidanau PES scheme, there appear to be no negative social consequences from the elite capture in the PES. We find that high social capital within communities has meditated the social tensions other studies attribute to elite capture. If elite capture is addressed by implementers, nonincome benefits can benefit the poor, for example with land tenure (Asquith et al. 2008, Caro-Borrero et al. 2015). Within our case study, the NGO believed that the wealth distribution and land ownership were homogenous across the communities (Leimona et al. 2010). Our results suggest that communities may be more resilient to social tensions surrounding elite capture if they have high social capital and the payments are not greatly increasing the participants' income. However, further research needs to assess the causal effect of social capital in alleviating tensions from PES schemes and elite capture within PES schemes.

Our study has some limitations. First, we faced some limitations in the data collection; when selecting the nonPES participants, we used a snowball sampling approach, which may have resulted in a bias of the respondents. Another limitation is that we assessed social capital at one point in time. This cross-sectional approach to data collection allows us to assess current levels of social capital between both PES and nonPES groups, but it prohibits us from identifying causality. Social capital develops over long periods of time (Leahy and Anderson 2010), thus demonstrating causality necessitates research time horizons beyond the scope and scale of this research. Adding to this, we also focus on social capital as an asset, ignoring migration-induced feedbacks (Rockenbauch and Sakdapolrak 2017). Finally, our study follows a similar limitation of many other social capital studies whereby we face an endogeneity issue, making it difficult to identify if the components (e.g., trust, networks) of social capital are outcomes or indicators of social capital (Durlauf 2002).

\section{CONCLUSIONS}

Our results suggest that, in the studied communities with high social capital, participants mediated the negative social spillovers that the PES scheme created. This mediation occurred through two pathways. First, participants shared information with 
nonparticipants about the scheme and how join it. Second, participants gave money to their jealous nonparticipating neighbors. Despite evidence of potential elite capture, we find that this did not cause any issues. Our results suggest that high social capital or the fact that the economic incentive was not enough to significantly increase the participants' income can effectively alleviate the social tensions that a PES program can have on rural communities.

Responses to this article can be read online at: http://www.ecologyandsociety.org/issues/responses. $\mathrm{php} / 10181$

\section{Acknowledgments:}

FLM would like to thank the Singapore International Graduate Award (SINGA) and the Rufford Small Grants for Nature Conservation for funding the data collection. All authors are grateful for thoughts and comments from Richard Belcher, Thomas Pienkowski, and members of the BioEcon lab.

\section{LITERATURE CITED}

Adger, W. N. 2003. Social capital, collective action, and adaptation to climate change. Economic Geography 79(4):387404. http://dx.doi.org/https://doi.org/10.1111/j.1944-8287.2003. tb00220.x

Adhikari, K. P., and P. Goldey. 2010. Social capital and its "downside:" the impact on sustainability of induced communitybased organizations in Nepal. World Development 38(2):184-194. http://dx.doi.org/10.1016/j.worlddev.2009.10.012

Asquith, N. M., M. T. Vargas, and S. Wunder. 2008. Selling two environmental services: in-kind payments for bird habitat and watershed protection in Los Negros, Bolivia. Ecological Economics 65(4):675-684. http://dx.doi.org/10.1016/j.

ecolecon.2007.12.014

Baker, S., and F. S. Chapin, III. 2018. Going beyond "it depends:" the role of context in shaping participation in natural resource management. Ecology and Society 23(1):20. http://dx.doi.org/ https://doi.org/10.5751/ES-09868-230120

Ballet, J., N. Sirven, and M. Requiers-Desjardins. 2007. Social capital and natural resource management: a critical perspective. The Journal of Environment and Development 16(4):355-374. http://dx.doi.org/10.1177/1070496507310740

Barnaud, C., E. Corbera, R. Muradian, N. Salliou, C. Sirami, A. Vialatte, J.-P. Choisis, N. Dendoncker, R. Mathevet, C. Moreau, V. Reyes-García, M. Boada, M. Deconchat, C. Cibien, S. Garnier, R. Maneja, and M. Antona. 2018. Ecosystem services, social interdependencies, and collective action: a conceptual framework. Ecology and Society 23(1): 15. http://dx.doi. org/10.5751/ES-09848-230115

Becchetti, L., S. Castriota, and P. Conzo. 2013. Cooperative membership as a trust and trustworthiness reinforcing device: results from a field experiment in the Philippines. The Journal of Development Studies 49(3):412-425. http://dx.doi. org/10.1080/00220388.2012.729047
Bennett, N. J. 2016. Using perceptions as evidence to improve conservation and environmental management. Conservation Biology 30(3):582-592. http://dx.doi.org/https://doi.org/10.1111/ cobi. 12681

Bodin, Ö., and B. I. Crona. 2008. Management of natural resources at the community level: exploring the role of social capital and leadership in a rural fishing community. World Development 36(12):2763-2779. http://dx.doi.org/10.1016/j. worlddev.2007.12.002

Bodin, Ö., G. Robins, R. McAllister, A. Guerrero, B. Crona, M. Tengö, and M. Lubell. 2016. Theorizing benefits and constraints in collaborative environmental governance: a transdisciplinary social-ecological network approach for empirical investigations. Ecology and Society 21(1): 40. http://dx.doi.org/10.5751/ ES-08368-210140

Bouma, J., E. Bulte, and D. van Soest. 2008. Trust and cooperation: scial capital and community resource management. Journal of Environmental Economics and Management 56(2):155166. http://dx.doi.org/10.1016/j.jeem.2008.03.004

Bowen, J. R. 1986. On the political construction of tradition: Gotong Royong in Indonesia. The Journal of Asian Studies 45 (3):545-561. http://dx.doi.org/10.2307/2056530

Burnham, K. P., and D. R. Anderson. 2002. Model selection and multimodel inference: a practical information-theoretic approach. Springer Science and Business Media 488.

Campos, A. C. V., C. M. Borges, A. M. D. Vargas, V. E. Gomes, S. D. Lucas, and E. Ferreira. 2015. Measuring social capital through multivariate analyses for the IQ-SC. BMC Research Notes 8:11. http://dx.doi.org/10.1186/s13104-015-0978-2

Caro-Borrero, A., E. Corbera, K. C. Neitzel, and L. AlmeidaLeñero. 2015. "We are the city lungs": payments for ecosystem services in the outskirts of Mexico City. Land Use Policy 43:138148. http://dx.doi.org/10.1016/j.landusepol.2014.11.008

Corbera, E., K. Brown, and W. N. Adger. 2007. The equity and legitimacy of markets for ecosystem services. Development and Change 38(4):587-613. http://dx.doi.org/10.1111/j.1467-7660.2007.00425. $\underline{\mathrm{X}}$

Cranford, M., and S. Mourato. 2011. Community conservation and a two-stage approach to payments for ecosystem services. Ecological Economics 71:89-98. http://dx.doi.org/10.1016/j. ecolecon.2011.08.007

Dasgupta, A., and V. A. Beard. 2007. Community driven development, collective action and elite capture in Indonesia. Development and Change 38(2):229-249. http://dx.doi.org/10.1111/ j.1467-7660.2007.00410.x

Dessie, Y., M. Wurzinger, and M. Hauser. 2012. The role of social learning for soil conservation: the case of Amba Zuria land management, Ethiopia. International Journal of Sustainable Development and World Ecology 19(3):258-267. http://dx.doi. org/10.1080/13504509.2011.636082

Djamhuri, T. L. 2008. Community participation in a social forestry program in Central Java, Indonesia: the effect of incentive structure and social capital. Agroforestry Systems 74(1):83-96. http://dx.doi.org/10.1007/s10457-008-9150-5 
Durlauf, S. N. 2002. On the empirics of social capital. The Economic Journal 112(483):F459-F479. http://dx.doi. org/10.1111/1468-0297.00079

Farley, J., and R. Costanza. 2002. Envisioning shared goals for humanity: a detailed, shared vision of a sustainable and desirable USA in 2100. Ecological Economics 43(2):245-259. http://dx.doi. org/https://doi.org/10.1016/S0921-8009(02)00218-5

Field, J. 2008. Social capital. Routledge, London, UK.

García-Amado, L. R., M. Ruiz Pérez, I. Iniesta-Arandia, G. Dahringer, F. Reyes, and S. Barrasa. 2012. Building ties: social capital network analysis of a forest community in a biosphere reserve in Chiapas, Mexico. Ecology and Society 17(3): 3. http:// dx.doi.org/10.5751/ES-04855-170303

Global Land Tool Network (GLTN). 2015. Land tenure security in selected countries - global report. GLTN, Nairobi, Kenya.

Gómez-Baggethun, E., R. de Groot, P. L. Lomas, and C. Montes. 2010. The history of ecosystem services in economic theory and practice: from early notions to markets and payment schemes. Ecological Economics 69(6):1209-1218. http://dx.doi.org/10.1016/ j.ecolecon.2009.11.007

Greble, W. E. 1979. A bold yeomanry: social change in a wheat belt district, Kulin, 1848-1970. Creative Research, Perth, Australia.

Grootaert, C., D. Narayan, M. Woolcock, and V. Nyhan-Jones. 2004. Measuring social capital: an integrated questionnaire. The World Bank, Washington, D.C., USA. http://dx.doi. org/10.1596/0-8213-5661-5

Guerrero, A. M., and K. A. Wilson. 2017. Using a socialecological framework to inform the implementation of conservation plans. Conservation Biology 31(2):290-301. http:// dx.doi.org/10.1111/cobi.12832

Ho, D., K. Imai, G. King, E. Stuart, and A. Whitworth. 2017. MatchIt: nonparametric preprocessing for parametric casual inference. Journal of Statistical Software 42(8): 1-28 http://dx.doi. org/10.18637/jss.v042.i08

Huang, M., S. K. Upadhyaya, R. Jindal, and J. Kerr. 2009. Payments for watershed services in Asia: a review of current initiatives. Journal of Sustainable Forestry 28(375):5517575. http:// dx.doi.org/10.1080/10549810902794287

Infield, M., and A. Namara. 2001. Community attitudes and behaviour towards conservation: an assessment of a community conservation programme around Lake Mburo National Park, Uganda. Oryx 35(1):48-60. http://dx.doi.org/https://doi.org/10.1017/ $\underline{\mathrm{S} 0030605300031537}$

Koontz, T. M., D. Gupta, P. Mudliar, and P. Ranjan. 2015. Adaptive institutions in social-ecological systems governance: a synthesis framework. Environmental Science \& Policy 53:139-151. http://dx.doi.org/10.1016/j.envsci.2015.01.003

Krishna, A., and N. Uphoff. 1999. Mapping and measuring social capital : a conceptual and empirical study of collective action for conserving and developing watersheds in Rajasthan, India. The World Bank, Washington, D.C., USA.

Kusumasari, B., and Q. Alam. 2012. Local wisdom-based disaster recovery model in Indonesia. Disaster Prevention and
Management: An International Journal 21(3):351-369. http://dx. doi.org/10.1108/09653561211234525

Lapeyre, R., R. Pirard, and B. Leimona. 2015. Payments for environmental services in Indonesia: what if economic signals were lost in translation? Land Use Policy 46:283-291. http://dx. doi.org/https://doi.org/10.1016/j.landusepol.2015.03.004

Lauber, T. B., D. J. Decker, and B. A. Knuth. 2008. Social networks and community-based natural resource management. Environmental Management 42(4):677-687. http://dx.doi.org/10.1007/s00267-008-9181-8

Leahy, J. E., and D. H. Anderson. 2010. "Cooperation gets it done": social capital in natural resources management along the Kaskaskia River. Society and Natural Resources 23(3):224-239. http://dx.doi.org/10.1080/08941920802378897

Lee, Y., I. P. Rianti, and M. S. Park. 2017. Measuring social capital in Indonesian community forest management. Forest Science and Technology 13(3):133-141. http://dx.doi.org/10.1080/21580103.$\underline{2017.1355335}$

Leimona, B., R. Pasha, and N. P. Rahadian. 2010. The livelihood impacts of incentive payments for watershed management in Cidanau Watershed, West Java, Indonesia. Pages 106-128in L. Tacconi, S. Mahanty, and H. Suich, editors. Payments for environmental services, forest conservation and climate changelivelihoods in the REDD. Edward Elgar Publishing, Cheltenham, UK. http://dx.doi.org/10.4337/9781849806015.00011

McDougall, C., and M. R. Banjade. 2015. Social capital, conflict, and adaptive collaborative governance: exploring the dialectic. Ecology and Society 20(1): 44. http://dx.doi.org/10.5751/ ES-07071-200144

Narloch, U., U. Pascual, and A. G. Drucker. 2013. How to achieve fairness in payments for ecosystem services? Insights from agrobiodiversity conservation auctions. Land Use Policy 35:107118. http://dx.doi.org/10.1016/j.landusepol.2013.05.002

Nieratkaa, L. R., D. B. Bray, and P. Mozumder. 2015. Can payments for environmental services strengthen social capital, encourage distributional equity, and reduce poverty? Conservation and Society 13(4): 345.

Oh, H., M.-H. Chung, and G. Labianca. 2004. Group social capital and group effectiveness: the role of informal socializing ties. The Academy of Management Journal 47(6):860-875. http:// dx.doi.org/10.5465/20159627

Ostrom, E. 1990. Governing the commons: the evolution of institutions for collective action. Cambridge University Press, Cambridge, UK. http://dx.doi.org/https://doi.org/10.1017/ $\underline{\text { CBO9780511807763 }}$

Ostrom, E. 1999. Social capital: a fad or a fundamental concept? Pages 172-214 in P. Dasgupta and I. Serageldin, editors. Social capital: a multifaceted perspective. The World Bank, Washington, D.C., USA.

Ostrom, E., and T. K. Ahn. 2003. Foundations of social capital. Abridged edition edition. Edward Elgar Publishing, Cheltenham, UK.

Ostrom, E., and T. K. Ahn. 2007. The meaning of social capital and its link to collective action. SSRN Scholarly Paper, Social Science Research Network, Rochester, New York, USA. 
Pascual, U., J. Phelps, E. Garmendia, K. Brown, E. Corbera, A. Martin, E. Gomez-Baggethun, and R. Muradian. 2014. Social equity matters in payments for ecosystem services. BioScience 64 (11):1027-1036. http://dx.doi.org/10.1093/biosci/biu146

Plummer, R., and J. FitzGibbon. 2006. People matter: the importance of social capital in the co-management of natural resources. Natural Resources Forum 30(1):51-62. http://dx.doi. org/10.1111/j.1477-8947.2006.00157.x

Pretty, J., and D. Smith. 2004. Social capital in biodiversity conservation and management. Conservation Biology 18(3):631638. http://dx.doi.org/10.1111/j.1523-1739.2004.00126.x

Ramirez-Sanchez, S., and E. Pinkerton. 2009. The impact of resource scarcity on bonding and bridging social capital: the case of fishers' information-sharing networks in Loreto, BCS, Mexico. Ecology and Society 14(1): 22. http://dx.doi.org/https://doi. org/10.5751/ES-02841-140122

Rockenbauch, T., and P. Sakdapolrak. 2017. Social networks and the resilience of rural communities in the global south: a critical review and conceptual reflections. Ecology and Society 22(1): 10. http://dx.doi.org/10.5751/ES-09009-220110

Sommerville, M., J. P. G. Jones, M. Rahajaharison, and E. J. Milner-Gulland. 2010. The role of fairness and benefit distribution in community-based payment for environmental services interventions: a case study from Menabe, Madagascar. Ecological Economics 69(6):1262-1271. http://dx.doi.org/10.1016/ j.ecolecon.2009.11.005

Tacconi, L., S. Mahanty, and H. Suich. 2009. Assessing the livelihood impacts of payments for environmental services: implications for avoided deforestation. Research Summary, Crawford School of Economics and Government, Canberra, Australia.

Teshome, A., J. de Graaff, and A. Kessler. 2016. Investments in land management in the north-western highlands of Ethiopia: the role of social capital. Land Use Policy 57:215-228. http://dx. doi.org/10.1016/j.landusepol.2016.05.019

Thuy, N. N., P. Dwivedi, F. Rossi, J. R. R. Alavalapati, and B. Thapa. 2011. Role of social capital in determining conservation attitude: a case study from Cat Tien National Park, Vietnam. International Journal of Sustainable Development and World Ecology 18(2):143-153. http://dx.doi.org/10.1080/13504509.2011.560455

To, P. X., W. H. Dressler, S. Mahanty, T. T. Pham, and C. Zingerli. 2012. The prospects for payment for ecosystem services (PES) in Vietnam: a look at three payment schemes. Human Ecology 40 (2):237-249. http://dx.doi.org/10.1007/s10745-012-9480-9

Turiansky, A. 2010. Measuring the effects of compensation for environmental services interventions on social norms and conservation behavior in Bolivia. Thesis, Nicholas School of the Environment, Duke University, Durham, North Carolina, USA.

Wall, E., G. Ferrazzi, and F. Schryer. 1998. Getting the goods on social capital. Rural Sociology 63(2):300-322. http://dx.doi.org/ https://doi.org/10.1111/j.1549-0831.1998.tb00676.x

Wollebaek, D., and P. Selle. 2002. Does participation in voluntary associations contribute to social capital? The impact of intensity, scope, and type. Nonprofit and Voluntary Sector Quarterly 31 (1):32-61. http://dx.doi.org/10.1177/0899764002311002
Woolcock, M., and D. Narayan. 2000. Social capital: implications for development theory, research, and policy. The World Bank Research Observer 15(2):225-249. http://dx.doi.org/10.1093/ wbro/15.2.225 
Appendix 1. Supplementary information (Part $1=$ Table 1 is the descriptive statistics of the social capital results; Part $2=$ Copy of survey instrument).

Table S1 - All variables collected and data distribution.

\begin{tabular}{|c|c|c|c|c|}
\hline Grouping & Variables & Variable type & PES (n=68) & nonPES $(n=68)$ \\
\hline \multicolumn{5}{|l|}{ Social capital } \\
\hline \multirow[t]{6}{*}{$\begin{array}{l}\text { Groups and } \\
\text { Networks }\end{array}$} & $\begin{array}{l}\text { A. Would you be able to borrow } \\
\text { money to cover one week's } \\
\text { household expenses? }\end{array}$ & $\begin{array}{l}\text { Ordinal - Very unlikely (1) to } \\
\text { very likely (5) }\end{array}$ & $\begin{array}{l}1-0 \% \\
2-0 \% \\
3-6 \% \\
4-84 \% \\
5-10 \%\end{array}$ & $\begin{array}{l}1-0 \% \\
2-1 \% \\
3-12 \% \\
4-71 \% \\
5-16\end{array}$ \\
\hline & $\begin{array}{l}\text { B. Are people in this group } \\
\text { mostly the same religion? }\end{array}$ & Binary - Yes (1), No (0) & $\begin{array}{l}\text { Yes }-100 \% \\
\text { No }-0 \%\end{array}$ & $\begin{array}{l}\text { Yes- } 99 \% \\
\text { No- } 1 \%\end{array}$ \\
\hline & $\begin{array}{l}\text { C. Are people in this group } \\
\text { mostly the same gender? }\end{array}$ & Binary - Yes (1), No (0) & $\begin{array}{l}\text { Yes }-38 \% \\
\text { No }-62 \%\end{array}$ & $\begin{array}{l}\text { Yes }-66 \% \\
\text { No- } 34 \%\end{array}$ \\
\hline & $\begin{array}{l}\text { D. Are people in this group } \\
\text { mostly the same ethnicity? }\end{array}$ & Binary - Yes (1), No (0) & $\begin{array}{l}\text { Yes }-99 \% \\
\text { No- } 1 \%\end{array}$ & $\begin{array}{l}\text { Yes }-97 \% \\
\text { No }-3 \%\end{array}$ \\
\hline & $\begin{array}{l}\text { E. Do most people have the } \\
\text { same job? }\end{array}$ & Binary - Yes (1), No (0) & $\begin{array}{l}\text { Yes }-40 \% \\
\text { No- } 60 \%\end{array}$ & $\begin{array}{l}\text { Yes }-65 \% \\
\text { No- } 35 \%\end{array}$ \\
\hline & $\begin{array}{l}\text { F. Does this group interact with } \\
\text { people outside of the } \\
\text { village? }\end{array}$ & Binary - Yes (1), No (0) & $\begin{array}{l}\text { Yes- } 35 \% \text {, } \\
\text { No- } 65 \%\end{array}$ & $\begin{array}{l}\text { Yes }-49 \% \\
\text { No }-51 \%\end{array}$ \\
\hline \multirow[t]{2}{*}{ Trust and solidarity } & $\begin{array}{l}\text { G. You have to be alert so that } \\
\text { someone does not take } \\
\text { advantage of you. }\end{array}$ & $\begin{array}{l}\text { Ordinal - Strongly disagree } \\
\text { (1) to strongly agree (5) }\end{array}$ & $\begin{array}{l}1-0 \% \\
2-0 \% \\
3-6 \% \\
4-43 \% \\
5-51 \%\end{array}$ & $\begin{array}{l}1-0 \% \\
2-4 \% \\
3-4 \% \\
4-47 \% \\
5-44 \%\end{array}$ \\
\hline & $\begin{array}{l}\text { H. Most people in the village } \\
\text { are willing to help if they } \\
\text { need it. }\end{array}$ & $\begin{array}{l}\text { Ordinal - Strongly disagree } \\
\text { (1) to strongly agree (5) }\end{array}$ & $\begin{array}{l}1-0 \% \\
2-0 \% \\
3-9 \% \\
4-50 \% \\
5-41 \%\end{array}$ & $\begin{array}{l}1-0 \% \\
2-1 \% \\
3-4 \% \\
4-51 \% \\
5-43 \%\end{array}$ \\
\hline
\end{tabular}

1 We collected data on the farmers groups and networks including what groups are the most important to the household. Most farmers included both their farmer group and religious groups within this. However due to social stigma farmers felt uncomfortable not choosing the religious groups as the most important to the household. Because of this, we will only be presenting the data on answers relaying to the farmer group. 


\begin{tabular}{|c|c|c|c|c|}
\hline & I. Trust of village & $\begin{array}{l}\text { Ordinal - very distrusting (1) } \\
\text { to very trusting (5) }\end{array}$ & $\begin{array}{l}1-1 \%, \\
2-19 \%, \\
3-13 \%, \\
4-52 \%, \\
5-15 \%\end{array}$ & $\begin{array}{l}1-0 \% \\
2-13 \% \\
3-22 \% \\
4-60 \% \\
5-4 \%\end{array}$ \\
\hline & J. Trust of district & $\begin{array}{l}\text { Ordinal - very distrusting (1) } \\
\text { to very trusting (5) }\end{array}$ & $\begin{array}{l}1-0 \% \\
2-24 \% \\
3-22 \% \\
4-47 \% \\
5-7 \%\end{array}$ & $\begin{array}{l}1-0 \% \\
2-24 \% \\
3-31 \% \\
4-43 \% \\
5-3 \%\end{array}$ \\
\hline & K. Trust of province & $\begin{array}{l}\text { Ordinal - very distrusting (1) } \\
\text { to very trusting (5) }\end{array}$ & $\begin{array}{l}1-1 \%, \\
2-34 \%, \\
3-18 \%, \\
4-38 \%, \\
5-9 \%\end{array}$ & $\begin{array}{l}1-0 \% \\
2-25 \% \\
3-38 \% \\
4-32 \% \\
5-4 \%\end{array}$ \\
\hline & $\begin{array}{ll}\text { L. Do you trust your farmer } \\
\text { group? }\end{array}$ & Binary - Yes (1), No (0) & $\begin{array}{l}\text { Yes }-97 \% \\
\text { No }-3 \%\end{array}$ & $\begin{array}{l}\text { Yes }-94 \% \\
\text { No- } 6 \%\end{array}$ \\
\hline & $\begin{array}{l}\text { M. Do you trust people in the } \\
\text { village? }\end{array}$ & Binary - Yes (1), No (0) & $\begin{array}{l}\text { Yes }-90 \% \\
\text { No- } 10 \%\end{array}$ & $\begin{array}{l}\text { Yes }-87 \% \\
\text { No }-13 \%\end{array}$ \\
\hline & $\begin{array}{l}\text { N. Do you trust outsiders of the } \\
\text { village? }\end{array}$ & Binary - Yes (1), No (0) & $\begin{array}{l}\text { Yes }-8 \% \\
\text { No- } 92 \%\end{array}$ & $\begin{array}{l}\text { Yes }-12 \% \\
\text { No }-88 \%\end{array}$ \\
\hline $\begin{array}{l}\text { Collective action and } \\
\text { cooperation }\end{array}$ & $\begin{array}{l}\text { O. If there is a problem in the } \\
\text { village everyone will work } \\
\text { together and cooperate to } \\
\text { solve the problem. }\end{array}$ & $\begin{array}{l}\text { Ordinal - Strongly disagree } \\
\text { (1) to strongly agree (5) }\end{array}$ & $\begin{array}{l}1-0 \% \\
2-0 \% \\
3-28 \% \\
4-34 \% \\
5-38 \%\end{array}$ & $\begin{array}{l}1-0 \% \\
2-0 \% \\
3-22 \% \\
4-26 \% \\
5-51 \%\end{array}$ \\
\hline $\begin{array}{l}\text { Information and } \\
\text { communication }\end{array}$ & $\begin{array}{l}\text { Do differences (in income, } \\
\text { social status, wealth, race, } \\
\text { religion, political beliefs) } \\
\text { define the village? }\end{array}$ & $\begin{array}{l}\text { Ordinal - Strongly disagree } \\
\text { (1) to strongly agree (5) }\end{array}$ & $\begin{array}{l}1-0 \% \\
2-54 \% \\
3-37 \% \\
4-6 \% \\
5-3 \%\end{array}$ & $\begin{array}{l}1-7 \% \\
2-40 \% \\
3-43 \% \\
4-3 \% \\
5-7 \%\end{array}$ \\
\hline & Q. Do you feel safe at home? & $\begin{array}{l}\text { Ordinal - Strongly disagree } \\
\text { (1) to strongly agree (5) }\end{array}$ & $\begin{array}{l}1-0 \% \\
2-0 \% \\
3-4 \% \\
4-77 \% \\
5-19 \%\end{array}$ & $\begin{array}{l}1-0 \% \\
2-0 \% \\
3-3 \% \\
4-66 \% \\
5-31 \%\end{array}$ \\
\hline & $\begin{array}{ll}\text { R. How many times in the past } \\
\text { month have you eaten or }\end{array}$ & Numeric & $\begin{array}{l}\text { Lowest - } 1 \\
\text { Highest - } 25\end{array}$ & $\begin{array}{l}\text { Lowest - 1, } \\
\text { Highest - 20, }\end{array}$ \\
\hline
\end{tabular}




\begin{tabular}{|c|c|c|c|c|}
\hline & $\begin{array}{l}\text { had drinks with someone at } \\
\text { home or in a public place? }\end{array}$ & & Mean - 4.647 & Mean - 5.706 \\
\hline & $\begin{array}{l}\text { S. Are the people you socialize } \\
\text { with a different ethnicity? }\end{array}$ & Binary - Yes (1), No (0) & $\begin{array}{l}\text { Yes }-7 \% \\
\text { No }-93 \% \\
\end{array}$ & $\begin{array}{l}\text { Yes }-3 \% \\
\text { No }-97 \% \\
\end{array}$ \\
\hline & $\begin{array}{l}\text { T. Are the people you socialize } \\
\text { with a different economic } \\
\text { status? }\end{array}$ & Binary - Yes (1), No (0) & $\begin{array}{l}\text { Yes - } 100 \% \\
\text { No }-0 \%\end{array}$ & $\begin{array}{l}\text { Yes }-99 \% \\
\text { No }-1 \%\end{array}$ \\
\hline & $\begin{array}{l}\text { U. Are the people you socialize } \\
\text { with a different social status } \\
\text { (i.e. cleric, teacher)? }\end{array}$ & Binary - Yes (1), No (0) & $\begin{array}{l}\text { Yes - } 100 \% \\
\text { No }-0 \%\end{array}$ & $\begin{array}{l}\text { Yes }-99 \% \\
\text { No }-1 \%\end{array}$ \\
\hline & $\begin{array}{l}\text { V. Are the people you socialize } \\
\text { with a different religion? }\end{array}$ & Binary - Yes (1), No (0) & $\begin{array}{l}\text { Yes }-9 \% \\
\text { No }-97 \%\end{array}$ & $\begin{array}{l}\text { Yes }-1 \% \\
\text { No }-99 \%\end{array}$ \\
\hline \multirow[t]{2}{*}{$\begin{array}{l}\text { Empowerment and } \\
\text { political action }\end{array}$} & $\begin{array}{l}\text { W. Do you feel happy in } \\
\text { general? }\end{array}$ & $\begin{array}{l}\text { Ordinal - Strongly disagree } \\
\text { (1) to strongly agree (5) }\end{array}$ & $\begin{array}{l}1-0 \% \\
2-0 \% \\
3-18 \% \\
4-68 \% \\
5-15 \%\end{array}$ & $\begin{array}{l}1-0 \% \\
2-6 \% \\
3-25 \% \\
4-68 \% \\
5-1 \%\end{array}$ \\
\hline & $\begin{array}{ll}X . & \text { Can they make important life } \\
\text { decisions and are able to } \\
\text { change their lives? }\end{array}$ & $\begin{array}{l}\text { Ordinal - Strongly disagree } \\
\text { (1) to strongly agree (5) }\end{array}$ & $\begin{array}{l}1-0 \% \\
2-7 \% \\
3-7 \% \\
4-69 \% \\
5-16 \% \\
\end{array}$ & $\begin{array}{l}1-1 \% \\
2-4 \% \\
3-16 \% \\
4-63 \% \\
5-15 \% \\
\end{array}$ \\
\hline \multicolumn{5}{|l|}{ Demographics } \\
\hline & 1. Family head & Binary - Yes (1), No (0) & $\begin{array}{l}\text { Yes }-99 \% \\
\text { No }-1 \%\end{array}$ & $\begin{array}{l}\text { Yes }-91 \% \\
\text { No }-9 \%\end{array}$ \\
\hline & 2. Farmer group leader & Binary - Yes (1), No (0) & $\begin{array}{l}\text { Yes }-10 \% \\
\text { No }-90 \%\end{array}$ & $\begin{array}{l}\text { Yes }-10 \% \text {, } \\
\text { No }-90 \%\end{array}$ \\
\hline & 3. Age & Numeric - in years & $\begin{array}{l}\text { Lowest- } 25 \\
\text { Highest - } 80 \\
\text { Mean }-49\end{array}$ & $\begin{array}{l}\text { Lowest - } 25 \\
\text { Highest - } 73 \\
\text { Mean - } 46.94\end{array}$ \\
\hline & 4. Education & Numeric - in years & $\begin{array}{l}\text { Lowest - } 1 \\
\text { Highest - } 14 \\
\text { Mean - } 6.632\end{array}$ & $\begin{array}{l}\text { Lowest - } 2 \\
\text { Highest - } 17 \\
\text { Mean }-6.221\end{array}$ \\
\hline & 5. Family help on plot & Binary - Yes (1), No (0) & $\begin{array}{l}\text { Yes }-64 \% \\
\text { No }-36 \%\end{array}$ & $\begin{array}{l}\text { Yes }-91 \% \\
\text { No }-9 \%\end{array}$ \\
\hline & $\begin{array}{l}\text { 6. Number of family living in } \\
\text { house }\end{array}$ & $\begin{array}{l}\text { Numeric - number of } \\
\text { persons }\end{array}$ & $\begin{array}{l}\text { Lowest }-0 \\
\text { Highest }-9 \\
\text { Mean } 4.397\end{array}$ & $\begin{array}{l}\text { Lowest - } 0 \\
\text { Highest - } 10 \\
\text { Mean } 4.279\end{array}$ \\
\hline
\end{tabular}




\begin{tabular}{|c|c|c|c|c|}
\hline & 7. Second job & Binary - Yes (1), No (0) & $\begin{array}{l}\text { Yes - 37\% } \\
\text { No - } 63 \%\end{array}$ & $\begin{array}{l}\text { Yes - 35\% } \\
\text { No - } 65 \%\end{array}$ \\
\hline & 8. Come from area & Binary - Yes (1), No (0) & $\begin{array}{l}\text { Yes }-6 \% \\
\text { No }-94 \%\end{array}$ & $\begin{array}{l}\text { Yes }-3 \% \\
\text { No }-97 \%\end{array}$ \\
\hline \multicolumn{5}{|l|}{ Assets } \\
\hline & 9. Loan & Binary - Yes (1), No (0) & $\begin{array}{l}\text { Yes - } 6 \% \\
\text { No }-94 \%\end{array}$ & $\begin{array}{l}\text { Yes }-91 \% \\
\text { No }-9 \%\end{array}$ \\
\hline & 10. Asset level & $\begin{array}{l}\text { Categorical - Low (1), } \\
\text { Medium (2), High (3) }\end{array}$ & $\begin{array}{l}\text { Low - 38\% } \\
\text { Medium - } 37 \% \\
\text { High - } 25 \%\end{array}$ & $\begin{array}{l}\text { Low - 9\% } \\
\text { Medium - } 82 \% \\
\text { High - 9\% }\end{array}$ \\
\hline \multicolumn{5}{|l|}{ Plot characteristics } \\
\hline & 11. Average plot size & Numeric - in hectares & $\begin{array}{l}\text { Lowest }-0.06 \\
\text { Highest }-1.50 \\
\text { Mean }-.5348\end{array}$ & $\begin{array}{l}\text { Lowest - .01 } \\
\text { Highest - } 2 \\
\text { Mean - .6316 }\end{array}$ \\
\hline & $\begin{array}{l}\text { 12. Average plot distance to } \\
\text { house }\end{array}$ & Numeric - walking minutes & $\begin{array}{l}\text { Lowest }-3 \\
\text { Highest - } 90 \\
\text { Mean }-24.55\end{array}$ & $\begin{array}{l}\text { Lowest - } 5 \text {, } \\
\text { Highest - } 120 \\
\text { Mean - } 24.48\end{array}$ \\
\hline & $\begin{array}{l}\text { 13. Average plot distance to } \\
\text { village }\end{array}$ & Numeric - walking minutes & $\begin{array}{l}\text { Lowest }-2 \\
\text { Highest - } 90 \\
\text { Mean }-31.51\end{array}$ & $\begin{array}{l}\text { Lowest - } 5 \\
\text { Highest - } 90 \\
\text { Mean - } 34.44\end{array}$ \\
\hline & 14. Multiple plots & Binary - Yes (1), No (0) & $\begin{array}{l}\text { Yes - } 79 \% \\
\text { No - } 21 \%\end{array}$ & $\begin{array}{l}\text { Yes }-24 \% \\
\text { No }-76 \%\end{array}$ \\
\hline & 15. Next to PES & Binary - Yes (1), No (0) & $\begin{array}{l}\text { Yes }-90 \% \\
\text { No- } 10 \%\end{array}$ & $\begin{array}{l}\text { Yes - } 15 \% \\
\text { No - } 85 \%\end{array}$ \\
\hline
\end{tabular}



SI - Copy of Survey

\section{SURVEY FOR FARMER GROUPS}

EXPLORING THE SOCIAL EQUITY IN PAYMENTS FOR ECOSYSTEM SERVICES, INDONESIA 2016

Thank you for agreeing to participate in this survey which is part of my $\mathrm{PhD}$ research. This survey is going to ask you about your relationships with other farmers in your village and your perceptions of the PES scheme. Before we start the survey, we will first ask you some background information about you and your farming. The survey is divided in 7 sections below.

Confidentiality - All information obtained, including your identity and responses to the survey will remain completely confidential.

Enumerator Name

Date

Start time End time

\section{A. FARMER DEMOGRAPHICS}


Location/Farmer Group (FG) details

1. Village name

2. Farmer name

3. Address and hp number

4. Are you a member of a farmer group?

$$
\begin{aligned}
& \square \text { Yes } \\
& \square \text { No }
\end{aligned}
$$

5. Name of farmer group

6. What year did you join the farmer group?

7. Are you the family head?

$$
\begin{aligned}
& \square \text { Yes } \\
& \square \text { No }
\end{aligned}
$$

8. Are you a leader of the farmer group (i.e. Leader, secretary, accountant)?

$$
\begin{aligned}
& \square \text { Yes } \\
& \square \text { No }
\end{aligned}
$$

9. Age

10. Years of education

11. Ethnicity

\begin{tabular}{|l|l|l|}
\hline $\begin{array}{c}\text { Name of working family } \\
\text { members }\end{array}$ & What is their job? & Do they help with the plot? \\
\hline & & \\
\hline & & \\
\hline & & \\
\hline & & \\
\hline & & \\
\hline
\end{tabular}

12. Number of family members in the house 
13. Main occupation

14. Second occupation

15. Do they come from this area?

$\square$ Yes

$\square$ No

a. If yes, how long have they lived here

16. Do they have a loan?

$\square$ Yes

$\square$ No

a. If yes, for how many years?

17. Aset apa yang bapak/ibu miliki?

\begin{tabular}{|c|l|l|l|l|l|}
\hline & Aset & Amount & & Aset & Amount \\
\hline a) & Car & & b) & Mobile phone & \\
\hline c) & Motorcycle & & d) & Bank account & \\
\hline e) & Bicycle & & f) & Gas stove & \\
\hline g) & Agriculture equipment & & h) & Chicken/stove & \\
\hline i) & T.V. & & j) & Goat & \\
\hline k) & Laptop & & l) & Buffalo/cow & \\
\hline m) & Satellite/antenna & & n) & electricity & \\
\hline
\end{tabular}




\begin{tabular}{|c|c|c|c|c|c|c|c|c|c|}
\hline Plot & $\begin{array}{l}\text { Size of } \\
\text { plot ha }\end{array}$ & $\begin{array}{l}\text { What do they } \\
\text { grow }\end{array}$ & $\begin{array}{l}\text { Land tenure } \\
\text { Milik/sewa/ } \\
\text { garap }\end{array}$ & $\begin{array}{l}\text { PES } \\
(\mathrm{Y} / \mathrm{N})\end{array}$ & $\begin{array}{l}\text { Minutes walked } \\
\text { from plot to } \\
\text { house }\end{array}$ & $\begin{array}{l}\text { Minutes } \\
\text { walked from } \\
\text { plot to center } \\
\text { of village }\end{array}$ & $\begin{array}{l}\text { Plot adjacent to } \\
\text { other farmers } \\
(\mathrm{Y} / \mathrm{N})\end{array}$ & $\begin{array}{l}\text { If yes, Adjacent } \\
\text { to other PES } \\
\text { farmers }(\mathrm{Y} / \mathrm{N})\end{array}$ & $\begin{array}{l}\text { Minutes walked to } \\
\text { closest PES } \\
\text { participant }\end{array}$ \\
\hline 1 & & & & & & & & & \\
\hline 2 & & & & & & & & & \\
\hline 3 & & & & & & & & & \\
\hline 4 & & & & & & & & & \\
\hline 5 & & & & & & & & & \\
\hline 6 & & & & & & & & & \\
\hline 7 & & & & & & & & & \\
\hline 8 & & & & & & & & & \\
\hline
\end{tabular}


Plot characteristics SOCIAL CAPITAL

\section{G1. Groups and networks}

1. I would like to start by asking you about the groups or organizations, networks, associations to which you or any member of your household belong. These could be formally organized groups or just groups of people who get together regularly to do an activity or talk about things. How many such groups are you or any one in your household a member? (Enumerator - groups can include, religious group, women group, youth group, farmer group, other)

\begin{tabular}{|c|c|c|c|c|c|c|c|c|c|}
\hline & Name & $\begin{array}{l}\text { Are people } \\
\text { mostly the } \\
\text { same } \\
\text { religion? } \\
\text { (Yes, No) }\end{array}$ & $\begin{array}{l}\text { Are people } \\
\text { mostly the } \\
\text { same } \\
\text { gender? } \\
\text { (Yes, No) }\end{array}$ & $\begin{array}{l}\text { Are people } \\
\text { mostly the } \\
\text { same } \\
\text { ethnicity? } \\
\text { (Yes, No) }\end{array}$ & $\begin{array}{l}\text { Are people } \\
\text { mostly of the } \\
\text { same } \\
\text { occupation? } \\
\text { (Yes, No) }\end{array}$ & $\begin{array}{l}\text { Are people } \\
\text { mostly of the } \\
\text { same level of } \\
\text { education? } \\
\text { (Yes, No) }\end{array}$ & $\begin{array}{l}\text { How often do you } \\
\text { meet? (Never, } \\
\text { Yes - sometimes, } \\
\text { Yes - often) }\end{array}$ & $\begin{array}{l}\text { Does the } \\
\text { group interact } \\
\text { with people } \\
\text { outside of the } \\
\text { village }\end{array}$ & $\begin{array}{l}\text { Which group is } \\
\text { most important to } \\
\text { you? }\end{array}$ \\
\hline $\begin{array}{l}\text { Group 1- } \\
\text { Agricultural } \\
\text { groups (PES, } \\
\text { farmer groups, } \\
\text { farm worker } \\
\text { groups) }\end{array}$ & & & & & & & & & \\
\hline $\begin{array}{l}\text { Group } 2- \\
\text { Community social } \\
\text { group (religion) }\end{array}$ & & & & & & & & & \\
\hline $\begin{array}{l}\text { Group 3- } \\
\text { Professional } \\
\text { groups (teachers, } \\
\text { civil servants) }\end{array}$ & & & & & & & & & \\
\hline
\end{tabular}


2. If you suddenly needed to borrow a small amount of money (enough to pay for the expenses of your household for 1 week), are there people beyond your immediate household and close relatives to whom you could turn and who would be willing and able to provide this money?

\begin{tabular}{|c|c|c|c|c|}
\hline Definitely not & Probably not & Unsure & Probably & Definitely \\
\hline 1 & 2 & 3 & 4 & 5 \\
\hline
\end{tabular}

\section{G2. Kepercayaan dan solidaritas}

1. Are you a trustworthy person or not to others?
$\square$ Trusted
$\square$ Not trusted

2. Do they trust other FG group members
$\square$ Yes
$\square$ No

3. Do they trust people in the village?
$\square$ Yes
$\square$ No

4. Trust outsiders of the village?
$\square$ Yes
$\square$ No

5. Do they agree/disagree with the following statement

- Most people in the village are willing to help if they need it

\begin{tabular}{|c|c|c|c|c|}
\hline $\begin{array}{c}\text { Strongly } \\
\text { disagree }\end{array}$ & $\begin{array}{c}\text { Disagree } \\
\text { somewhat }\end{array}$ & $\begin{array}{c}\text { Neither agree nor } \\
\text { disagree }\end{array}$ & $\begin{array}{c}\text { Agree } \\
\text { somewhat }\end{array}$ & $\begin{array}{c}\text { Strongly } \\
\text { agree }\end{array}$ \\
\hline 1 & 2 & 3 & 4 & 5 \\
\hline
\end{tabular}

- You always have to be alert so that someone does not take advantage of you.

\begin{tabular}{|c|c|c|c|c|}
\hline $\begin{array}{c}\text { Strongly } \\
\text { disagree }\end{array}$ & $\begin{array}{c}\text { Disagree } \\
\text { somewhat }\end{array}$ & $\begin{array}{c}\text { Neither agree nor } \\
\text { disagree }\end{array}$ & $\begin{array}{c}\text { Agree } \\
\text { somewhat }\end{array}$ & $\begin{array}{c}\text { Strongly } \\
\text { agree }\end{array}$ \\
\hline 1 & 2 & 3 & 4 & 5 \\
\hline
\end{tabular}


6. How much do they trust

- Village officials

\begin{tabular}{|c|c|c|c|c|}
\hline $\begin{array}{c}\text { To a very } \\
\text { small extent }\end{array}$ & $\begin{array}{c}\text { To a small } \\
\text { extent }\end{array}$ & $\begin{array}{c}\text { Neither great } \\
\text { nor small } \\
\text { extent }\end{array}$ & $\begin{array}{c}\text { To a great } \\
\text { extent }\end{array}$ & $\begin{array}{c}\text { To a very } \\
\text { great extent }\end{array}$ \\
\hline 1 & 2 & 3 & 4 & 5 \\
\hline
\end{tabular}

- District officials

\begin{tabular}{|c|c|c|c|c|}
\hline $\begin{array}{c}\text { To a very } \\
\text { small extent }\end{array}$ & $\begin{array}{c}\text { To a small } \\
\text { extent }\end{array}$ & $\begin{array}{c}\text { Neither great } \\
\text { nor small } \\
\text { extent }\end{array}$ & $\begin{array}{c}\text { To a great } \\
\text { extent }\end{array}$ & $\begin{array}{c}\text { To a very } \\
\text { great extent }\end{array}$ \\
\hline 1 & 2 & 3 & 4 & 5 \\
\hline
\end{tabular}

- Province officials

\begin{tabular}{|c|c|c|c|c|}
\hline $\begin{array}{c}\text { To a very } \\
\text { small extent }\end{array}$ & $\begin{array}{c}\text { To a small } \\
\text { extent }\end{array}$ & $\begin{array}{c}\text { Neither great } \\
\text { nor small } \\
\text { extent }\end{array}$ & $\begin{array}{c}\text { To a great } \\
\text { extent }\end{array}$ & $\begin{array}{c}\text { To a very } \\
\text { great extent }\end{array}$ \\
\hline 1 & 2 & 3 & 4 & 5 \\
\hline
\end{tabular}

7. If there was a project benefitting the village and not themselves would, they be willing to donate....

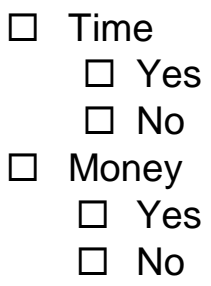

\section{G3. Aksi kolektif dan kerja sama}

1. In the past 12 months did you or anyone in your household participate in any communal activities, in which people came together to do some work for the benefit of the community

Yes

i. How many times in the past 12 months

No

2. If there is a problem in the village everyone will work together and cooperate to solve the problem.

\begin{tabular}{|c|c|c|c|c|}
\hline Not likely & & & & Very likely \\
\hline 1 & 2 & 3 & 4 & 5 \\
\hline
\end{tabular}




\section{G4. Information and communication}

1. Top three sources of information on whats happening in the village on development programs (such as agricultural extension, workfare, family planning etc.)?

Relatives, friends, and neighbours

Community bulletin board

Local market

$\square$ Community or local newspaper

National newspaper

Radio

Television
Groups or associations

Business or work associates

Political associates

$\square$ Community leaders

$\square$ An agent of the government

$\square$ NGOs

Internet

\section{G5. Social cohesion and inclusion}

1. Do the differences in income, social status, wealth, race, religion, political believes, define the village .

\begin{tabular}{|c|c|c|c|c|}
\hline $\begin{array}{c}\text { To a very } \\
\text { small extent }\end{array}$ & $\begin{array}{c}\text { To a small } \\
\text { extent }\end{array}$ & $\begin{array}{c}\text { Neither great } \\
\text { nor small } \\
\text { extent }\end{array}$ & $\begin{array}{c}\text { To a great } \\
\text { extent }\end{array}$ & $\begin{array}{c}\text { To a very } \\
\text { great extent }\end{array}$ \\
\hline 1 & 2 & 3 & 4 & 5 \\
\hline
\end{tabular}

they ever caused problems.

$$
\begin{aligned}
& \square \quad \text { Yes } \\
& \square \quad \text { No } \rightarrow \text { go to question } 5
\end{aligned}
$$

3. Dua perbedaan yang paling sering menimbulkan masalah? Two biggest problems.

$\square$ Differences in education

$\square$ Differences in landholding

$\square$ Differences in wealth/material possessions

$\square$ Differences in social status

$\square$ Differences between men and women

$\square$ Differences between younger and older generations
Differences between long-term and recent residents

Differences in political party affiliations

Differences in religious beliefs

Differences in ethnic or linguistic backgrounds/tribes

Other differences

4. How many times in the past month have they eaten or had some drinks with people, both at home and in other public places. 
5. The people you socialize with are...

a. Different ethnicity?

$\square$ Yes

$\square$ No

b. Different economic status

$\square$ Yes

$\square$ No

c. Different social status (hajj cleric, teacher, village head)

$\square$ Yes

$\square$ No

d. Different religion?

Yes

$\square$ No

6. Do you feel safe at home?

\begin{tabular}{|c|c|c|c|c|}
\hline Very unsafe & $\begin{array}{c}\text { Moderately } \\
\text { unsafe }\end{array}$ & $\begin{array}{c}\text { Neither safe } \\
\text { nor unsafe }\end{array}$ & $\begin{array}{c}\text { Moderately } \\
\text { safe }\end{array}$ & Very safe \\
\hline 1 & 2 & 3 & 4 & 5 \\
\hline
\end{tabular}

\section{G6. Empowerment and political actions}

1. Do they feel happy in general?

\begin{tabular}{|c|c|c|c|c|}
\hline Very unhappy & $\begin{array}{c}\text { Moderately } \\
\text { unhappy }\end{array}$ & $\begin{array}{c}\text { Neither happy nor } \\
\text { unhappy }\end{array}$ & $\begin{array}{c}\text { Moderately } \\
\text { happy }\end{array}$ & Very happy \\
\hline 1 & 2 & 3 & 4 & 5 \\
\hline
\end{tabular}

2. Can they make important life decisions? Able to change their lives?

\begin{tabular}{|c|c|c|c|c|}
\hline $\begin{array}{c}\text { Totally unable } \\
\text { to change life }\end{array}$ & $\begin{array}{c}\text { Mostly unable } \\
\text { to change life }\end{array}$ & $\begin{array}{c}\text { Neither able } \\
\text { nor unable }\end{array}$ & $\begin{array}{c}\text { Mostly able to } \\
\text { change life }\end{array}$ & $\begin{array}{c}\text { Totally able to } \\
\text { change life }\end{array}$ \\
\hline 1 & 2 & 3 & 4 & 5 \\
\hline
\end{tabular}

3. In the past 12 months, how often have people in this village got together to jointly petition government officials or political leaders for something benefiting the community
$\square$ Never
$\square$ Once
$\square$ A few times $(<5)$
Many times $(>5)$

4. Did they vote in the last elections/?
$\square$ Yes
$\square$ No 
Thank you for your time for the survey, it is now complete. 